\title{
An Examination of Inclusive Practices for Students with Learning Disabilities in Botswana: A Literature Review
}

\author{
Samantha L. Mrstik \\ Georgia Gwinnett College \\ Lisa A. Dieker \\ University of Central Florida \\ C. Okechukwu Abosi \\ University of Botswana
}

\begin{abstract}
The country of Botswana has passed laws to support the human rights of their citizens, including people with learning disabilities. In accordance with the United Nations' guidelines, Botswana's human rights initiatives, and the international movement toward inclusive education, inclusive educational reform is taking place. We have conducted a comprehensive literature review, the purpose of which was to establish the progress Botswana has made in special education policy, implementation of policy into schools, and the strides made toward inclusion. However, there are still many struggles comparable to many school systems in African nations. Key findings include a nation with significant developments in human rights which includes a developing inclusive education system with both policy and implementation, yet, still coping with the growing pains of a young special education program.
\end{abstract}

Special education in Botswana is a new and developing system, evolving today to include the creation of an inclusive education system in which students with disabilities typically attend the same classes as their non-disabled peers (Abosi, 2000; Dart, 2007; Mukhopadhyay et al., 2012). Currently no legal definition of the term "inclusion" exists in Botswana; the term is defined differently in various government documents. However, 
inclusion as a concept is discussed and is a part of government schools. Inclusive Education in Botswana:

includes, and meets the needs of all, including those with special educational needs, whatever their gender, life circumstances, health, disability, stage of development, capacity to learn, level of achievement, financial or any other circumstances. No one should be excluded from education. (Botswana Ministry of Education, 2014, p. 4)

As the special education system evolves in Botswana, more classifications of disabilities are being recognized, including students with learning disabilities (LDs; Abosi, 2007).

Since the onset of Botswana's special education system in 1994, the country has experienced the growing pains typical of many developing African countries trying to adopt a westernized educational concept and at times using the medical model promoting an ableism mentality. Although the government of Botswana has strived to uphold the values and human rights of the United Nations (UN) Salamanca Statement (Abosi, 2000), Botswana's special education program has experienced a lack of resources, limited teacher education programs, and cultural conflicts between traditional and modern values, leading to what Abosi (2007) referred to as the discrimination against people with disabilities.

This comprehensive literature review examines special education in Botswana, while focusing on a specific population, students with LDs, a population for which publications and governmental information are limited at this time. This comprehensive review begins with the history of special education and inclusion globally, then presents the parallel evolution of services in Botswana, including those for students with LDs. The review concludes with future topics to be explored for students with LDs in Botswana.

\section{Methodology}

We conducted a comprehensive literature review using available databases (e.g., ERIC, EBSCOHost, PsychINFO), primary sources (e.g., peer reviewed articles, theses, newspaper articles, and books) and historical documents (e.g., UN documents, policy documents from the government of Botswana, statistical reports from the government of Botswana and the UN). The term "comprehensive" refers to the exhaustion of sources located and reviewed by us. The topic of special education in the research community of Botswana is relatively new. Moreover, researchers are now exploring inclusion in Botswana, so we were able to comprehensively review the research and government documents relating to special education and inclusion for students with LD. Searches of these databases were conducted in English only and consisted of a combination of the following terms: "special education," "education," "inclusion," "Botswana," "Gaborone," "inclusive education," "learning disability," "specific learning disability," "specific learning disorder," "disability," "handicapped," "special needs," "elementary schools," "junior secondary school," and "secondary school." Years reviewed ranged from 1966, the year of Botswana's formation as a nation, through 2017. We reviewed full articles and abstracts. 


\section{Historical Context}

\section{International Development of Special Education}

In order to fully understand the emergence of inclusion in Botswana, one must understand the globalization and history of inclusion. The beginning of the globalization of special education began with creation of the UN on January 1, 1942 with 26 nations joining together to fight the Axis Powers of World War II. The joint efforts of these original 26 nations began discussions to form the collaboration now known as the UN. The UN was officially formed in 1945 with 51 member states (United Nations, 2016c) and has evolved and continues its focus on policies, often to serve those who have been disenfranchised in some way (e.g., immigrants, women, children with disabilities). The primary responsibility of the UN is to develop international law to serve as a framework for governments to create policies (United Nations, 2016b).

Table 1 provides an overview of the role of the $\mathrm{UN}$ in creating international laws for people with disabilities. In 1948, in a direct response to the atrocities of World War II, the UN Educational, Scientific, and Cultural Organization (UNESCO) wrote the Declaration of Human Rights. Article 1 of the Declaration of Human Rights (1948) stated, "All human beings are born free and equal in dignity and rights. They are endowed with reason and conscience and should act towards one another in a spirit of brotherhood" (p. 2). The wording of Article 1 set the tone of the declaration and was written in response to the prosecution of Nazi war criminals in the Nuremberg trials held from 1945 to 1949 (Library of Congress, 2014). Article 26 of the document was written to declare, "Everyone has a right to an education" (Article 26, para. 1) and proclaimed education as a human right (UN General Assembly, 1948). Declaring education as a basic human right opened the door of education for all students worldwide, including those with disabilities (United Nations, 2016b).

Despite the UN's 1948 declaration, it was not until 1981 that the International Year of Disabled Persons was declared. The UN General Assembly adopted the document of the World Programme of Action Concerning People with Disabilities in 1982, promoting global disability prevention, rehabilitation, and equality. The World Health Organization adopted the World Programme of Action and included definitions of "impairment," "disability," and "handicap." The document also defined the terms "prevention," "rehabilitation," and "equalization," creating a more standardized definition for the global community (UN General Assembly, 1982).

The World Programme of Action created a springboard for further evolution of disability services and policies being presented and adopted globally. In 1990, the Education for All document was written by UNESCO, the UN Development Programme, the UN Children's Fund (UNICEF), and the World Bank, the former three being divisions of the $\mathrm{UN}$ created to reduce world illiteracy and expand primary education for all nations. 
Table 1

International Policies and Developments That Influenced Special and Inclusive Education Globally

\begin{tabular}{|c|c|c|}
\hline Year & Policy/ Development & Outcome \\
\hline 1942 & $\begin{array}{l}\text { Franklin D. Roosevelt } \\
\text { coined the term "United } \\
\text { Nations" }\end{array}$ & $\begin{array}{l}\text { Twenty-six nations pledged to continue to fight the Axis } \\
\text { Powers of World War II. }\end{array}$ \\
\hline 1945 & Formation of the UN & $\begin{array}{l}\text { Primary responsibility of the UN to develop international law to } \\
\text { serve as a framework within which governments could create } \\
\text { policy. }\end{array}$ \\
\hline 1948 & $\begin{array}{l}\text { Declaration of Human } \\
\text { Rights }\end{array}$ & $\begin{array}{l}\text { "All human beings are born free and equal in dignity and } \\
\text { rights." }\end{array}$ \\
\hline 1981 & $\begin{array}{l}\text { International Year of } \\
\text { Disabled Persons }\end{array}$ & $\begin{array}{l}\text { The UN General Assembly adopted the World Programme of } \\
\text { Action Concerning People with Disabilities. }\end{array}$ \\
\hline 1982 & $\begin{array}{l}\text { World Programme of } \\
\text { Action Concerning } \\
\text { People with Disabilities }\end{array}$ & $\begin{array}{l}\text { The programme was used as a method to increase global } \\
\text { disability prevention, rehabilitation, and equality. Defined } \\
\text { "impairment," "disability," "handicap," "prevention," and } \\
\text { "rehabilitation." }\end{array}$ \\
\hline 1990 & Education for All Act & $\begin{array}{l}\text { Six goals: (a) Expand early childhood care and education; (b) } \\
\text { provide free and compulsory primary education for all; (c) } \\
\text { promote learning and life skills for young people and adults; (d) } \\
\text { increase adult literacy; (e) achieve gender parity; and (f) } \\
\text { improve the quality of education }\end{array}$ \\
\hline 1990 & $\begin{array}{l}\text { Convention on the } \\
\text { Rights of the Child }\end{array}$ & $\begin{array}{l}\text { Article } 2 \text {, non-discrimination, Article } 23 \text {, care of children with } \\
\text { disabilities, and Article } 28 \text {, right to an education }\end{array}$ \\
\hline 1993 & $\begin{array}{l}\text { Standard Rules on the } \\
\text { Equalization of } \\
\text { Opportunities for } \\
\text { Persons with Disabilities }\end{array}$ & $\begin{array}{l}\text { Twenty-two rules concerning the health, education, and } \\
\text { equality of people with disabilities and served as a guide for } \\
\text { policymakers worldwide. }\end{array}$ \\
\hline 1994 & Salamanca Statement & $\begin{array}{l}\text { Goal was to provide a framework on which governments could } \\
\text { base special education policy. Urged governments to adopt } \\
\text { policies that provided an inclusive education for men and } \\
\text { women with disabilities. }\end{array}$ \\
\hline 2000 & $\begin{array}{l}\text { Dakar Framework for } \\
\text { Action }\end{array}$ & $\begin{array}{l}\text { Six goals: (a) expansion of early childhood care and education, } \\
\text { (b) ensuring girls have access to free and compulsory } \\
\text { education, (d) ensuring the learning needs of all young people } \\
\text { and adults are met through appropriate learning, (d) achieving } \\
50 \% \text { improvement in literacy levels, (e) eliminating the gender } \\
\text { gap in primary and secondary education, and (f) improving } \\
\text { education so measurable outcomes are achieved by all. }\end{array}$ \\
\hline 2006 & $\begin{array}{l}\text { Convention on the } \\
\text { Rights of Persons with } \\
\text { Disabilities }\end{array}$ & $\begin{array}{l}\text { Goal of ensuring the quality of life of all human beings. } \\
\text { Article } 5 \text { requested governments recognize people with } \\
\text { disabilities as equal; Article } 6 \text { demanded governments protect } \\
\text { women and people with disabilities; Article } 7 \text { demanded } \\
\text { governments protect the rights of women and people with } \\
\text { disabilities }\end{array}$ \\
\hline
\end{tabular}


The passing of Education for All was paired with the ratification of the Convention on the Rights of the Child (UN General Assembly, 1990), which expanded upon six goals and contained specific actions for children with disabilities. The push for additional rules and standards for children with disabilities continued to be emphasized by UNESCO through the Standard Rules on the Equalization of Opportunities for Persons with Disabilities. The UN General Assembly adopted these rules and standards in December of 1993. The Standard Rules consisted of 22 rules concerning the health, education, and equality of people with disabilities and served as a guide for policymakers worldwide. Rule 6 of this document called for children and adults with disabilities to be afforded an education.

\section{The Salamanca Statement}

In an effort to continue the commitment to the Education for All declaration of 1990, a delegation representing 92 governments and 25 organizations met in Salamanca, Spain, in June of 1994, with the goal of furthering inclusive education on a worldwide basis. The Salamanca Statement: Framework for Action on Special Needs Education (UNESCO \& Spain Ministry of Education and Science, 1994) was written to further expand the special education initiative of Education for All (UNESCO, 1990).

The goal of the Salamanca Statement was to provide governments with a framework on which to base inclusive education policy. The writers of the UN statement urged governments to adopt these policies, including providing children with disabilities an inclusive education. In Article 7 of the Salamanca Statement, the fundamental principle of inclusive schooling is defined as:

\footnotetext{
All children should learn together, whenever possible, regardless of any difficulties or differences they may have. Inclusive schools must recognize and respond to diverse needs of their students, accommodating both different styles and rates of learning ensuring quality education to all through appropriate curricula, organizational arrangements, teaching strategies, resource use and partnerships with their communities. There should be a continuum of support and services to match the continuum of special needs encountered in every school. (UNESCO \& Spain Ministry of Education and Science, 1994, p. 11)
}

This definition was not created to eliminate the need for the special schools or special classrooms, but Article 9 states students should be served in the regular classroom unless the student is unable to make progress in the regular setting. Article 9 states that in countries with existing special education programs, staff in special units or special schools can be used for preparing general education teachers to work with students with special needs in the typical school. The statement adds that some special schools may be needed. Article 19 asserts that even students who are better served in special schools should be given the opportunity to attend the typical school part-time. Students who are deaf and blind are an exception to this rule. Because of the communication needs of students who are blind and deaf, Article 21 places an emphasis on learning proper communication skills and notes that in the case of these students, a specialized school may be more suitable for these unique populations. Article 25 allows for flexibility of coordinating services to meet each student's needs, which may include special schools, ordinary or typical schools, non-government organizations (NGOs), health, employment, and social services (UNESCO \& Spain Ministry of Education and Science, 1994). 
The Salamanca Statement delegates power to governments to monitor inclusive practices, and advises that data should be taken in the following areas: number of students enrolled in special schools and typical or regular schools, equipment used by students with disabilities, types of professionals needed to meet the needs of students with disabilities, and the finances being used nationally on this population. In addition, international partners and aid agencies are to monitor the usage of funding to support inclusive education practices.

Schools, both urban and rural, operated by governments using these guidelines are encouraged to communicate practices through the development of inclusive policies. The government is to ensure schools discourage prejudice against those with disabilities by cultivating an environment of inclusive practices for all, including in-service preparation for staff, faculty, and the public to promote awareness of best practices for serving children with disabilities (UNESCO \& Spain Ministry of Education and Science, 1994).

The changes described in the Salamanca Statement were not exclusive to students with disabilities but also were created to enhance the special education initiatives of Education for All. Education for All directed schools and governing bodies to adopt a child-centred approach to education. A child-centred approach was defined as a flexible and adaptive curriculum, which meets the needs of all learners and also meets the student's needs and interests. Under this policy, students with special needs are to receive additional instruction, but the content should be the same as their peers without disabilities. In order to better motivate all students, the content should be aligned to the student's interests and experiences. Teachers should monitor the progress of students by regularly using formative assessments. For students with disabilities, a continuum of services should be provided, which may include external resources and the use of appropriate and affordable technology to be used for mobility, communication, or learning (UNESCO \& Spain Ministry of Education and Science, 1994).

The Salamanca Statement defined an inclusive school as a place where all children learn together and the school delivers instruction to meet the needs of all students (UNESCO \& Spain Ministry of Education and Science, 1994). The authors of the Salamanca Statement encouraged flexible management of schools to allow for a variety of learning options to be deployed and teams of professionals to be formed. The responsibility lies with the school administrator to encourage students with disabilities to participate in the school and the community and to create an environment of acceptance within both. The entire community is encouraged to be accountable for the success of each child rather than solely the classroom teachers (UNESCO \& Spain Ministry of Education and Science, 1994).

The authors of the Salamanca Statement encouraged research-based practices to be used in the classroom. Special education research and development was to be integrated into national universities and centres for curriculum development. Teachers were encouraged to conduct action research to evaluate their instruction, and the data gathered was to be used to make choices for further instruction (UNESCO \& Spain Ministry of Education and Science, 1994).

The Salamanca Statement provides a platform for teacher-preparation programs to take a positive approach in instructing pre-service teachers to work with students with 
disabilities by providing them with instruction in assessing learning, adapting curriculum, using assistive technology, and individualizing instruction for all students, including students with disabilities. In addition, professional development on inclusive education is to be provided for all staff and faculty at schools. Universities are to take a major role in creating this professional development, linking research to practice.

Primary, junior secondary, and secondary schools were to consider the use of external support personnel for students with disabilities. These supports are to include educational psychologists, speech pathologists, occupational therapists, and/or advisory teachers. The use of school clusters, which allows professionals to work with students in a zone of schools rather than only in one school, also is suggested in the Salamanca Statement.

Sections E and F of the Salamanca Statement are identified as priorities in the field of global inclusive education. Section E emphasizes the need for early childhood education in addition to the early identification of disabilities, girls' education, and transition to adulthood. Section F of the Salamanca Statement reminds the international community that special education is not only the responsibility of the Ministry of Education, but also of the entire community, including the public, families, and NGOs. Parental partnerships are emphasized as critically important for the well-being of the child. Parents are encouraged to participate in their children's education, and schools should explain the progress of a student with disabilities in clear, jargon-free language. Communities also are to provide both in-school and out-of-school activities for students with disabilities. Neighbourhood centres, youth clubs, or other organizations are to help with homework assistance for families who cannot assist their children. The role of NGOs is to assist in special education programs by supporting new ideas and extending these ideas into the community. Moreover, Section 3 encourages NGOs and governments, both at the local and international level, to join forces to educate students with disabilities.

\section{After Salamanca}

In 2006, the Convention on the Rights of Persons with Disabilities (UN General Assembly, 2006) was assembled with the goal of ensuring the quality of life of all human beings. The Convention was established to assist people with disabilities in becoming more established in the mainstream world and to help combat discrimination against people with disabilities. The Convention addressed accessibility, mobility, health, education, employment, housing, and rehabilitation. With 82 countries involved, the Convention had the highest number of signatories in UN convention history (United Nations, 2016a)

Specific to education, Article 24 of the Convention on the Rights of Persons with Disabilities states, "Parties shall ensure an inclusive education system at all levels and lifelong learning" (UN General Assembly, 2006, Article 24, para. 1). The second section of this article includes persons with disabilities who should be able to receive free, quality, general education, with reasonable accommodations. The third and fourth sections state that appropriate communication skills should be taught to students who are 
deaf or blind. The final section discusses the need for accommodations in vocational and adult education (UN General Assembly, 2006).

\section{UN Millennium Development Goals}

During the 2000s the UN continued to promote inclusion of equality through the Dakar Framework for Action (UNESCO, 2000). The "Sub-Saharan Africa Framework" within the Dakar Framework for Action (2000) introduced the idea of the "the new vision of the African Renaissance" (UNESCO, 2000, p. 27). The framework states the four primary areas of focus for the region are: access and equity, quality and relevance, capacity building, and partnerships. "Access and equity" refers to the commitment to review and develop policy, restructure government finances, and develop a close relationship among government, schools, communities, and parents. The creators of the "Sub-Saharan Africa Framework" emphasized a need for special attention to be paid to street and working children, children in conflict areas, minority groups, refugees, and HIV/AIDS orphans. This framework emphasized girls should be included in science, technology, engineering, and mathematics (STEM)-related fields. Goals were created to improve the quality and relevance of educational changes in curriculum to include life skills such as dealing with HIV/AIDS. The writers focused on the improvement of teacher education, specifically in the areas of inclusion and technology, and defined a minimum level for teacher education. Goals also were created for the improvement of cost-effective learning materials for schools. Focus statements for institutional and professional capacity-building for greater efficiency and effectiveness were strengthened along with gender friendliness. Some of the areas listed as priority for improvement in the "Sub-Saharan Africa Framework" are social, cultural, and economic development of Africa; the assurance of a basic right to food, shelter, security, and health; and the involvement of teachers' unions in developing the teaching profession. The authors of "Sub-Saharan Africa Framework" recognized the need to improve the partnership between the federal government and a selection of groups and organizations; and they identified the need to collaborate with NGOs, communities, parents, teachers' associations, and ministries (UNESCO, 2000).

In 2002, the secretary-general of the UN wanted to create a plan to reduce the effects of poverty worldwide. The plan came to be known as the Millennium Development Goals (United Nations, 2015). Goal 2 of the Millennium Development Goals is dedicated to universal primary education for everyone, including students with disabilities. SubSaharan Africa has made the most significant improvement in school enrollment with an increase of 20\% from 2000 to 2015 (United Nations, 2015).

\section{Findings}

The Salamanca Statement provided a framework for developing countries to create or enhance inclusive education programs. After the Salamanca Statement was written, governments worldwide began to implement special education programs, in many cases using more inclusive models. Using the UN's policies as an exemplar, Botswana created a special education system, and later created an inclusive education system. 


\section{Botswana's Disability Policies and Practices}

Unlike many nations with emerging special education programs, Botswana has the financial backing and social conscience to implement special education initiatives. However, Botswana has shared many of the same difficulties as its African neighbors in the implementation of special education programs (Abosi, 2000). Botswana's constitution was written to protect the rights and freedoms of every individual (Government of Botswana, 1966). The government has worked to incorporate the philosophy of Kagisano, or social harmony, in all policies (Presidential Task Group, 2016). In line with this ideology, many of the policies of Botswana have focused on human rights. The "national principles of democracy, development, self-reliance, and unity" are infused into all development plans (Presidental Task Group, 2016, p. 4-5).

Botswana's peaceful history plays a key role in its interest in human rights. Formerly called Bechuanaland, Botswana was a British Protectorate in south central Africa that gained independence from the United Kingdom in 1966 (Main, 2010). A protectorate is defined as "the relation of a strong state towards a weaker state or territory that it protects and partly controls" ("Protectorate," 2016, para. 1). Botswana enjoyed a peaceful transition to independence, but at that time, Botswana was one of the poorest countries in the world (The World Bank, 2016).

Botswana has demonstrated the drive to create human rights initiatives, such as special education, and is able to finance these initiatives through the diamond industry. Diamonds were discovered in 1967 , and the economic trajectory of the country changed. The term "blood diamond" or "conflict diamond" has been used to describe the diamondmining industry in many African nations. The UN defined conflict diamonds as, "rough diamonds used by rebel movements or their allies to finance armed conflicts aimed at undermining legitimate governments" (Kimberley Process, 2016, Section 1). However, conflict diamonds have not fueled the economy of Botswana (Fortin, 2012; Jasmasmie, 2015; Koinange, 2006) because of its emphasis on human rights; and Botswana was one of the original governments to take part in drafting the Kimberley Process (Fortin, 2012; Kimberley Process, 2016). This process governs the fair trade of diamonds. De Beers, one of the largest diamond mining companies in the world, entered into a joint venture with the government of Botswana, creating a $50 \%$ split of profits (Koinange, 2006; Nocera, 2008). In return, De Beers sold the government of Botswana $15 \%$ of the De Beers Company (Nocera, 2008). Since De Beers' arrival in Botswana, the government has partnered with the company to create a number of initiatives, such as building roads, the creation of HIV prevention programs, and government supplied anti-retrovirals, all of which have benefited both parties (Koinange, 2006; Nocera, 2008). Botswana's governmental stability and strong democracy have enabled the country to become one of the fastest growing economies in the world (The World Bank, 2016). Botswana has been investing in education, health, and infrastructure and is now considered an upper-middleincome nation with a stable democracy, free elections, and a constitution providing fundamental rights to all (The World Bank, 2016). These developments have created the impetus for social programs such as special education.

With diamonds financing many infrastructure, health, and social programs, Botswana has been able to study its people to better meet their needs. Until 1991, people 
with disabilities in Botswana were not counted by the census, thereby not allowing policymakers to fully understand the need for special education for their citizens. According to the 2011 census, the population of Botswana was 2,024,904 people (Statistics Botswana, 2014). In the past, Botswana had used the World Health Organization's estimate indicating that $15 \%$ of the population are people with disabilities (World Health Organization, n.d.). The census from 2011 reported that the number of people with disabilities was 59,103 (2.92\% of the population; Statistics Botswana, 2014).

\section{Education in Botswana}

Since Botswana has developed social programs and financed them through the use of income from the diamond mines, education in Botswana is well funded. Botswana spent $9.6 \%$ of its gross national product on education in 2009 (World Bank, 2009), which made it the fifth highest ranking country in the world for money spent on education as a percentage of their gross national product (Statistics Botswana, 2014).

Students in Botswana study nine subjects: mathematics, English, Setswana (the national and majority language), science, social studies, agriculture, creative and performing arts, physical education, and moral studies. School is divided into lower and upper levels (UNESCO, 2011). The lower level consists of primary school which educates students, on average, ages 6-13. At the end of primary school, students take the Primary School Leaving Examination, after which they then enter compulsory junior secondary school for an additional 3 years (Abosi \& Otukile-Mongwaketse, 2017).

Upon completion of junior secondary school, students take another exam, the Junior Certificate Examination (UNESCO, 2011). Depending on the student's Junior Certificate Examination score, they may then apply to enter a senior secondary school. School fees are required for this level, and the admission process can be quite competitive. However, senior secondary school is not mandatory. Students who have not passed the examination given at the end of junior secondary school may attend a vocational school or go to work. To be eligible to attend a university, a student must have passed the Botswana General Certificate of Secondary Examination (Abosi \& Otukile-Mongwaketse, 2017).

\section{Evolution of Policy Reform and Special Education in Botswana}

Even though Botswana has enjoyed much prosperity, it still experiences problems typical of developing nations. Like other African school systems, Botswana has had a history of inconsistencies such as frequent policy and curriculum changes. Furthermore, a study by Abosi (2007) revealed that in many cases, teachers have not been prepared to educate students with disabilities; the typical class size is 40 students with a range of abilities; school infrastructure is poor, and some schools in rural areas are still held outside. In addition, students often are affected by HIV/AIDS and poverty, which may adversely affect student motivation (Abosi, 2007).

Compounding these challenges, in some cases students with disabilities have experienced mistreatment or abuse at the hands of their teachers. Shumba and Abosi (2011) conducted a study of 31 students, ranging in age from 16 to 20 years, with a variety of disabilities, in five schools outside of the capital city of Gaborone. Of those 
surveyed, many students had suffered abuses at the hand of a teacher. The students reported that teachers had asked them to wash pots and pans $(70 \%)$, to sell freezits (popsicles) or sweets (54\%), or had called them inappropriate names (71\%). Seventy-four percent of female students reported having their breasts touched or knew of another student with a disability who had their breasts touched by a teacher. Furthermore, an alarming 54\% of the students surveyed were forced to have sex with their teachers. When asked why, $45 \%$ of students said it was because of a belief that young girls with disabilities were virgins, and thus free of HIV/AIDS (Shumba \& Abosi, 2011). Many people believe people with disabilities are virgins, so they often fall victim to sexual abuse. Although there were limitations to this study due to the small sample size $(N=31)$, and because participants were all from the Gaborone area, the study still revealed beliefs that local teachers and the society in general might have about students with disabilities.

Botswana has attempted to develop policies to address these problems as well as the perceptions and treatment of people with disabilities. The government of Botswana developed the first National Policy on Education in 1977 moving from an educational platform for the privileged to increased funding, initially at the primary level (Botswana Ministry of Education, 1977). This policy provided a framework for universal access for all primary-aged children in the country with the intent being to increase human-resource capital in the country. However, this initial legislation did not include students with disabilities. The National Policy on Education white paper outlined the problems of the educational system at the time as not having enough emphasis on primary education; not enough preparation for the world of work; little opportunity for non-traditional students; gaps in education quality in rural schools; and private, for-profit schools, which are often inferior to government-funded schools. After outlining these shortfalls, the government described strategies for improvement in each area. An emphasis was placed on the improvement of primary schools, teacher preparation, the abolishment of school fees for primary school, and literacy instruction occurring in Setswana and English. Goals also changed for secondary education. Junior secondary schools were established, extending to ten years students' access to free public education (Botswana Ministry of Education, 1977). Although the government made great strides with the National Policy on Education, special education was not included in these forward movements (Mukhopadhyay et al., 2012).

In 1993, the Government of Botswana assessed the problems they faced in educating students with disabilities. Although Botswana is a middle-income nation, appropriate resources have not always been provided to schools. The government found issues such as a lack of trained staff, not enough educational testing to diagnose students with disabilities, no specific curricula, not enough reliable data, and poor early intervention and identification across school sites (Dart, Didimalang, \& Pilime, 2002). Since that time, government policies have been written in Botswana to try to alleviate the problems in schools serving students with disabilities (Botswana Ministry of Education, 1994, 2014).

Historically, special education in Africa was provided by NGOs and churchaffiliated groups (Abosi, 2007; Dart et al., 2002) with few written policies existing to protect or educate people with disabilities. Similar to much of Africa, church groups started educating students with disabilities in Botswana in 1969, when missionaries from 
the Dutch Reformed Church began to educate the blind; the Lutheran Church began to educate the deaf in 1970 (Brandon, 2006; Mukhopadhyay et al., 2012). Initially, only students with disabilities who were visible in society, such as those with physical impairments or intellectual disabilities, were served. Students without a visible disability, such as students with a LD or an emotional behavioural disorder, were educated in the general education classroom with no accommodations provided.

The path toward special education continued in 1981-1982, when the Swedish International Development Agency assisted Botswana in creating the first special education unit in the Ministry of Education (Dart et al., 2002). In 1984, Botswana developed its first policy on special education by promoting early assessment and equal opportunity (Dart et al., 2002). The National Development Plan VI (1985) recommended mainstreaming students with disabilities (Dart et al., 2002).

Even with the resistance of some Batswana (plural for the people of Botswana), in 1996, the government of Botswana furthered their approach to working with people with disabilities to enhance lives through the National Policy on Care for People with Disabilities (Botswana Ministry of Health, 1996), based on the guidelines of the $U N$ World Programme of Action Concerning Disabled Persons (UN General Assembly, 1982). Several of these guidelines focused on education for students with disabilities. Through this policy, the responsibilities of agencies involved in the care of people with disabilities were outlined, beginning with the responsibilities of the state. The government of Botswana proposed to "prevent the social, emotional and physical deprivation of an individual" (UN General Assembly, 1982, p. 6). The Office of the President was to advance policies for the welfare of students with disabilities and advocate for public and private resources for students with disabilities. The Ministry of Education was, and still is, expected to establish and maintain special education programs, policy, guidelines, and support for NGOs working in education. The Ministry of Health was expected to continue prevention services, introduce rehabilitation facilities, assist NGOs working in health care, and continue to support the medical professionals who work with people with disabilities in education and training settings (Ministry of Health Botswana, 1996).

Botswana instituted the Revised National Policy on Education in 1994, which recommended the inclusion of students with disabilities in public schools (Botswana Ministry of Education, 1994). With many similarities to the Salamanca Statement (UNESCO \& Spain Ministry of Education and Science, 1994), the policy established special education teacher preparation facilities at the University of Botswana and Tlokweng College of Education and began requiring pre-service general educators to take classes in special education practices (Abosi, 2000). Since then, additional legislation has been passed, demonstrating the government's commitment to educating all students. The government of Botswana continues to guide policymaking with the four national principles of democracy, self-reliance, unity, and development, pursuant to the national philosophy of Kagisano (Tabulawa, 1998).

In September of 2014, the Ministry of Education created the Inclusive Education Policy. The ministry's goal for this policy was to provide equal access to an inclusive education regardless of "gender, age, life circumstances, health, disability, stage of 
development, capacity to learn, or socio-economic circumstance" (p. 1). The government of Botswana has stated that the rationale for this policy is to comply with international human rights policy and to ensure each member of society has the right to thrive.

\section{Special Education in Botswana}

Currently, Botswana uses two definitions of disability. The first has been adapted from the definition of disability from the World Health Organization: "restrictions in the use, or loss of body limbs, sight, intellect, speech, etc." (Statistics Botswana, 2014, p. 203). This definition and the definition by Oliver and Barnes (1998) ${ }^{1}$ are used interchangeably in the 2011 census, as are the terms "impairment" and "disability" as indicated here:

Long term impairment, be it physical, mental, intellectual, or sensory, whether congenital or acquired which, when combined with environmental and societal barriers limits the person's ability to function in society on an equal basis with others who have no impairment. The limitations include inability to carry out activities of daily living independently. (Statistics Botswana, 2014, p. 204)

Botswana's Ministry of Education has recognized six categories of special education: visual impairment, hearing impairment, speech and language difficulties, intellectual disabilities, LDs, and physical disabilities (Abosi \& Otukile-Mongwaketse, 2017). Ministry officials have begun to reference the term "autism." The category of emotional behavioural disorder has not been used in Botswana.

Students in Botswana are diagnosed with a disability by a team of professionals located at the Central Resource Centre, which provides assessments for the entire country of Botswana. A student can be referred for testing through a parent or guardian, school officials, or health officials. The Central Resource Centre staff members complete the initial evaluation when they visit the schools (Abosi \& Otukile-Mongwaketse, 2017).

Much like other nations, students with disabilities in Botswana must be assessed prior to receiving an Individual Education Programme (IEP), which provides them with services (Abosi \& Otukile-Mongwaketse, 2017; Mangope et al., 2012). However, Botswana does not have clear policies on the assessment for placement of students with disabilities (Mangope et al., 2012). Mangope et al. (2012) conducted a study of the Central Resource Centre, the sole entity for assessing students in Botswana, and found they were aware of their inability to reach all students who needed assessments in the country, as they are limited by location and staffing. Mangope et al. (2012) also stated that many schools' teachers might not have the preparation to know when to refer students for testing. Furthermore, there is limited information available to determine the instruments the Central Resource Centre uses to evaluate a student with disabilities, and government guidelines and definitions of the six categories of disabilities used in Botswana cannot be found online.

\footnotetext{
1 "Any loss or abnormality of psychological, physiological, or anatomical structure or function" (Oliver \& Barnes, 1998, p. 15).
} 


\section{Inclusion in Botswana}

Botswana's policy now mandates that students with mild to moderate intellectual disabilities and LDs be engaged in the inclusive education system (Botswana Ministry of Education, 2014). Students with other types of disabilities are to be educated in special schools or special education units attached to schools (Abosi \& OtukileMongwaketse, 2017).

\section{Teachers' Perceptions of Inclusion}

Many teachers in Botswana have had difficulty embracing the new idea of inclusion, and have expressed negativity about including students with disabilities in their classes (Brandon, 2006; Chhabra et al., 2010; Nthitu, 2011; Mukhopadhyay et al., 2012). Some studies indicate that teachers prefer students with certain types of disabilities like LDs or physical impairments (Mukhopadhyay et al., 2012). Many teachers expressed opinions related to the lack of preparation, difficulty in dealing with student behavioural problems, large class size, and lack of facilities and resources. Moreover, many senior teachers, who have taught for many years, may not have had any courses in special education (Mukhopadhyay et al., 2012). Likewise, Mangope and Mukhopadhyay (2015) concluded that few general and special educators collaborate regularly, and most general educators felt they were unprepared to teach students with disabilities in an inclusive setting.

\section{Pre-service Teachers' Perceptions of Inclusion}

Concerns about inclusion have not been limited to working teachers; pre-service teachers have had similar concerns. In a survey of 202 university students in Ghana and Botswana, pre-service teachers were worried about their ability to provide equal attention to all students, working with students with severe disabilities, and the lack of funding (Kuyini \& Mangope, 2011). Mukhopadhyay et al. (2009) reported that pre-service teachers were concerned about working with students with disabilities because of student behavioural problems, though teachers in the school expected the pre-service teachers majoring in special education would be able to solve all student behaviour problems. Preservice teachers revealed that they felt oppressed by other faculty and students at University of Botswana, and that they were made to feel as if their chosen field was unimportant (Mukhopadhyay et al., 2009). However, as the pre-service teachers' levels of education increased, their attitudes became more positive. Forty-seven postgraduate diploma education students enrolled in a special education course at the University of Botswana were given a pre and post questionnaire. The post questionnaire results indicated increased comfort and confidence in teaching students with disabilities in their classes (Otukile-Mongwaketse \& Mukhopadhyay, 2013).

Among the concerns of pre-service teachers in Botswana are the traditional beliefs regarding disability. A study by Dart (2006) revealed that many of the university preservice teachers believed people with disabilities were cursed by God or were the children of witches. Some students expressed fear of people with disabilities, and others suggested that students with disabilities were not able to learn. These traditional beliefs and misconceptions are prevalent and discriminate in many ways against people with disabilities in Botswana. University students are being educated to challenge traditional 
beliefs. However, some of the general public still believe people with disabilities are cursed. Modernization is a new concept in Botswana, and with modernization have come new ideas that seem liberal and often confusing to the Tswana (people from all tribal ethnicities of Botswana) who have moved from rural areas (Livingston, 2005). Even though policies have changed regarding special education in Botswana, many people have received misinformation about students with disabilities.

\section{Teacher Education in Botswana}

Teachers in Botswana may opt for one of three types of teaching degrees: the Primary Teaching Certificate, the 3-year program only offered at a teachers' training college, and the 4-year bachelors degree offered at the University of Botswana (Mukhopadhyay, 2015). As part of the Revised National Policy on Education of 1994 all teacher-education programs require courses in special education. Currently, degrees in special education can only be obtained from the University of Botswana in Gaborone in the areas of intellectual disabilities, LD, visual impairments, and hearing impairments. Besides the program at the University of Botswana, five other teacher-training programs exist in Botswana, three focusing on primary and two on secondary education (OtukileMongwaketse \& Mukhopadhyay, 2013).

Since the University of Botswana graduated the first group of special education teachers in 1997, the demand has continued to grow (Abosi, 2000). A persistent shortage exists in Botswana, and the distribution of these teachers has not been even throughout the country (Abosi, 2000). The Revised National Policy on Education (Botswana Ministry of Education, 1994) mandates that each primary school have a Senior Teacher of Learning Difficulties; however, few schools actually have filled the position (Dart, 2007). Because of this increased need for special educators, the University of Botswana has created an in-service diploma for working teachers and a pre-service double major program. Special education majors are expected to choose one of four specialization categories: learning difficulties, visual impairments, hearing impairments, or intellectual disabilities (Abosi \& Otukile-Mongwaketse, 2017).

\section{Learning Disabilities}

Students with disabilities in Botswana also have been reported as having difficulties (e.g., poor grades, disciplinary problems) in school (Abosi, 2007). Students with LDs have had a very different set of problems in the inclusive setting compared to their peers without disabilities. A very clear definition of an inclusive classroom has been written into the Inclusive Education Policy (2014), with Batswana officials recognizing that students with LDs are to be incorporated into the inclusive classroom. However, there is not a clear definition of what constitutes an LD in the context of Botswana. The term was coined in the United States by Samuel Kirk in 1963 (Kirk, 1981); and although the definition has changed throughout the years as more research has become available, all revisions to the definition remain clear and consistent in the use of the term in the United States. In Africa the term has been defined using the original westernized definition presented by Kirk (1971) and parts of the U.S. definitions written in the Individuals with Disabilities Education Act (2004). Generally, African educators use the term "learning 
disability" for a student who experiences learning difficulties without a physical disability; but in most African nations, including Botswana, no firm definition exists (Abosi, 2007). African educators are reported to believe that a student with LD can learn, but it may take them longer to comprehend (Abosi, 2007).

Abosi (2007) outlined problems that have faced students with LDs in Botswana's school system. He explained that large class size, poor classroom management, and frequent educational reforms have led to changes in the school routine and structure, while curriculum changes and new grading schemes have left many students with LD struggling to keep up. Promotion to the next grade level has been determined by either examination or automatic promotion. In either situation, students with LDs often feel discouraged because they did not pass the examination, or because they feel they were promoted without knowing the skills necessary for the next class level (Abosi, 2007). Moreover, with only two tracks in Botswana's school system, special school or regular school, many students with LDs do not qualify for special school, but do not have the necessary accommodations to succeed in regular school, so they have fallen behind their peers (Raditoaneng, 2011).

The Curriculum Development Division of the Ministry of Education has recommended changes to improve the learning of all students, including less "chalk and talk" and more differentiated instruction or the use of Universal Design for Learning (Abosi \& Otukile-Mongwaketse, 2017). These changes can only enhance the classroom experience for students with LDs, but general education teachers do not feel prepared to teach such students and have shared their concerns about making changes in their classrooms. They also feel they lack professional development on inclusion and on teaching students with LDs in the typical classroom (Mangope \& Mukhopadhyay, 2015). Yet, what professional development is needed, especially for teaching students with disabilities, is yet to be determined.

\section{Conclusion}

Like many other nations worldwide, Botswana's special or inclusive education system began in 1994 and was based on the Salamanca Statement. Botswana instituted the Revised National Policy on Education (1994), which recommended the inclusion of students with disabilities in public schools. Due to Botswana's emphasis on civil rights, its strong economy, and its stable government, special education and inclusive education continues to expand.

Even with this expansion, Botswana experiences many of the same problems and challenges as do other educational systems in Africa, such as large class size and poor school infrastructure (Abosi, 2007). Students often are unmotivated to participate in school due to families in poverty or affected by HIV/AIDS (Abosi, 2007). In addition, students with disabilities have not always been fully embraced in schools in Botswana. Some teachers have indicated feeling very negatively about the inclusion of students with physical disabilities in their classes (Brandon, 2006). Other teachers have been concerned about disruptive students and students with disabilities lagging behind their peers in their classes (Chhabra et al., 2010). However, teacher-education programs are changing perceptions about inclusion. Pre-service teachers are challenging traditional 
beliefs that people with disabilities are cursed (Livingston, 2005) and are gaining a more modernized perspective.

This modernization of education in Botswana includes access and educational opportunities for students with LDs. However, the current challenge will be to ensure teachers are prepared to work with this population through a lens of strengths, not deficits. Without a clear and consistent definition of LDs, students entering the classroom may differ greatly in their range of abilities. The early development of services for students with disabilities provides Botswana with an opportunity for change, unlike other countries with deep-rooted practices, beliefs, or misconceptions. Botswana, in its Education for Kagisano, focused on social harmony, has the opportunity to replace ableism as the focus of their educational practices. Instead, there is great potential to ground their special or inclusive education practices in the true spirit of the four principles of Kagisano: democracy, development, self-reliance, and unity. Creating an education system in a country based on these principles and using these principles to support students with LDs could create an international model of practice. As these students are now in settings with their non-disabled peers, this approach is no longer conceptual, but is to be truly reflective in practice.

Due to inclusion in Botswana's schools, students have grown more accustomed to working and playing with students with disabilities. In a study by Nthitu (2011) teacher participants reported students with disabilities felt a sense of acceptance by the other students in the school and mentioned that they encouraged this acceptance. Mukhopadhyay et al. (2012) stated that primary school students at the research site did not seem to have problems playing, eating, or working together in classes. Yet, will equity be established and will college and career access for students with disabilities be equal to their non-disabled peers? This is an area that will be better determined in the next decade.

Special education and inclusion are present in Botswana. The foundation has been laid through the educational policies and special education research outlined in this examination of the current practices for students with LDs. The combination of policies and economic and government stability, blended with a strong social conscience, are developing into the strong inclusive education system, in which students with LDs can thrive and become valuable members of society.

\section{References}

Abosi, O. (2007). Educating children with learning disabilities in Africa. Learning Disabilities Research \& Practice, 22(3), 196-201. . https://doi.org/10.1111/j.1540-5826.2007.00242.x

Abosi, O. C. (2000). Trends and issues in special education in Botswana. Journal of Special Education, 34(1), 48-53. https://doi.org/10.1177\%2F002246690003400105

Abosi, O., \& Otukile-Mongwaketse, M. (2017). Special education in Botswana. In M. L. Wehmeyer \& J. R. Patton (Eds.), Praeger international handbook of special education (Vol. 1, pp. 314331). Praeger.

Botswana Ministry of Education. (1977). National policy on education (Government Paper No. 1).

Botswana Ministry of Education. (1994). Revised national policy on education, April 1994 (Government Paper No. 2). 
Botswana Ministry of Education. (2014). Inclusive education policy. https://unevoc.unesco.org/eforum/moesd_inclusive-education-policy.pdf

Botswana Ministry of Health. (1996). National policy on the care for people with disabilities (No. 5/96). https://www.mindbank.info/item/2134

Brandon, D. P. (2006). Botswana's family and consumer science teachers' attitude towards the inclusion of students with physical disabilities. Journal of Family and Consumer Sciences Education, 24(1), 37-49. https://www.natefacs.org/Pages/v24no1/v24no1Brandon.pdf

Chhabra, S., Srivastava, R., \& Srivastava, I. (2010). Inclusive education in Botswana: The perceptions of school teachers. Journal of Disability Policy Studies, 20(4), 219-228. https://doi.org/10.1177/1044207309344690

Dart, G. (2006). "My eyes went wide open": An evaluation of the special needs education awareness course at Molepolole college of education, Botswana. British Journal of Special Education, 33(3), 130-138. https://doi.org/10.1111/j.1467-8578.2006.00428.x

Dart, G. (2007). Provision for learners with special educational needs in Botswana: A situational analysis. International Journal of Special Education, 22(2), 56-66. https://eric.ed.gov (Doc. EJ814489)

Dart, G., Didimalang, C., \& Pilime, S. (2002). An evaluation of special units for children with mental retardation at Botswana primary schools (pp. 1-102). Botswana Educational Research Association. https://eprints.worc.ac.uk/444/

Fortin, J. (2012, August 16). De Beers moves to Botswana, Africa's conflict-free diamond in the rough. International Business Times. http://www.ibtimes.com/de-beers-moves-botswanaafricas-conflict-free-diamond-rough-747494

Government of Botswana. Constitution of Botswana (1966). //www.parliament.gov.bw/images /constitution.pdf

Government of Botswana. (2011). Access to basic education. http://www.gov.bw/en/Ministries-Authorities/Ministries/Ministry-of-Agriculture1/Teachers/Universal-Primary-Education/ (now only available at archive.org)

Jasmasmie, C. (2015). De Beers closing another diamond mine: This time in Botswana. MINING.com. http://www.mining.com/de-beers-closing-another-diamond-mine-this-time-in-botswana/

Individuals with Disabilities Education Act, 20 U.S.C. § 1400 (2004).

Kimberley Process. (2016). FAQ: Find answers to the big challenges we face [Web page]. http://www.kimberleyprocess.com/en/faq

Kirk, S. (1981). Learning disabilities: A historical note. Academic Therapy, 17(1), 5-11. https://doi.org/10.1177/105345128101700101

Kirk, S. A., \& Kirk, W. D. (1971). Psycholinguistic learning disabilities: Diagnosis and remediation (ED051605). ERIC. https://eric.ed.gov/?id=ED051605

Koinange, J. (2006, December 15). Gem-of-a-deal spares Botswana from blood diamonds. CNN.com: World. http://www.cnn.com/2006/WORLD/africa/12/11/koinange.botswana/index.html ?eref=rss_topstories

Kuyini, A. B., \& Mangope, B. (2011). Student teachers' attitudes and concerns about inclusive education in Ghana and Botswana. International Journal of Whole Schooling, 7(1), 20-37. http://www.wholeschooling.net/Journal_of_Whole_Schooling/IJWSIndex.html

Library of Congress. (2014, June). Nuremberg trials. https://www.loc.gov/rr/frd/Military_Law Nuremberg_trials.html

Livingston, J. (2005). Debility and the moral imagination in Botswana. Indiana University Press. 
Main, M. (2010). Culture smart! Botswana: The essential guide to customs \& culture. Kuperard.

Mangope, B., \& Mukhopadhyay, S. (2015). Preparing teachers for inclusive education in Botswana: The role of professional development. Journal of International Special Needs Education, 18(2), 60-72. https://doi.org/10.9782/2159-4341-18.2.60

Mangope, B., Bawa Kuyini, A., \& Major, T. (2012). Assessment of learners with special needs for inclusive education in Botswana: Issues and challenges for schools. International Journal of Scientific Research in Education, 5(2), 138-150. https://www.ijsre.com/assets/vol.\%2c-5_2_mangope-et-al.pdf

Mukhopadhyay, S. (2015). West is best? A post-colonial perspective on the implementation of inclusive education in Botswana. KEDI Journal of Educational Policy, 12(1), 19-39. https://www.kedi.re.kr/eng/kedi/bbs/B0000005/list.do?menuNo=200067

Mukhopadhyay, S., Molosiwa, S., \& Moswela, E. (2009). Teacher trainees' level of preparedness for inclusive education in Botswana schools: Need for change. International Journal of Scientific Research in Education, 2(2), 51-58. http://www.ijsre.com/past-issues.html

Mukhopadhyay, S., Nenty, H. J., \& Abosi, O. (2012). Inclusive education for learners with disabilities in Botswana primary schools. SAGE Open, 2(2). https://doi.org/10.1177/2158244012451584

Nocera, J. (2008, August 8). Diamonds are forever in Botswana. The New York Times. http://www.nytimes.com/2008/08/09/business/worldbusiness/09nocera.html

Nthitu, J. M. (2011). Teachers' perspectives on inclusion of disabled learners in Botswana [Doctoral dissertation, University of Cape Town]. https://open.uct.ac.za/handle/11427/29115

Oliver, M., \& Barnes, C. (1998). Disabled people and social policy: From exclusion to inclusion. Longman.

Otukile-Mongwaketse, M., \& Mukhopadhyay, S. (2013). Botswana PDGE student teachers' attitude towards inclusive education: Implication for teacher education. Turkish Journal of Teacher Education, 2(1), 36-46. http://www.tujted.com/arsiv/160

Presidential Task Group. (2016). A long term vision for Botswana.

"Protectorate." (n.d.). Dictionary.com. Retrieved September 2016 from http://www.dictionary.com /browse/protectorate

Raditoaneng, W. (2011). Education for children with learning difficulties using Botswana as a case study. Journal of Innovative Research in Education, 1(1), 67-85.

Shumba, A., \& Abosi, O., C. (2011). The nature, extent and causes of abuse of children with disabilities in schools in Botswana. International Journal of Disability, Development \& Education, 58(4), 373-388. https://doi.org/10.1080/1034912X.2011.626664

Statistics Botswana. (2014). Population and housing census 2011: Analytical report. https://www.statsbots.org.bw/sites/default/files/publications/F0007909559_GUIDE\%20TO\% 20THE\%202011\%20POPULATION\%20AND\%20HOUSING_0.pdf

United Nations. (2015). The Millennium Development Goals report 2015. http://www.un.org /millenniumgoals/2015_MDG_Report/pdf/MDG\%202015\%20rev\%20(July\%201).pdf

United Nations. (2016a). Division for social policy and development. https://www.un.org /development/desa/en/about/desa-divisions/social-policy.html

United Nations. (2016b). Global issues at the UN. https://www.un.org/en/sections/issues-depth/globalissues-overview/

United Nations. (2016c). History of the United Nations. http://www.un.org/en/sections/history/historyunited-nations/index.html 
United Nations Educational, Scientific and Cultural Organization. (1990). Education for all: World declaration on education for all and framework for action to meet basic learning needs. http://unesdoc.unesco.org/images/0012/001275/127583e.pdf

United Nations Educational, Scientific and Cultural Organization. (2000). The Dakar framework for action: Education for all: Meeting our collective commitments. https://unesdoc.unesco.org /ark:/48223/pf0000120240

United Nations Educational, Scientific and Cultural Organization. (2011). Botswana. In International Bureau of Education, World data on education 2010/11 (7th ed.). http://www.ibe.unesco.org /fileadmin/user_upload/Publications/WDE/2010/pdf-versions/Botswana.pdf

United Nations Educational, Scientific and Cultural Organization \& Spain Ministry of Education and Science. (1994). The Salamanca statement and framework for action on special education (ED-94/WS/1 8). https://unesdoc.unesco.org/archives

United Nations General Assembly, International bill of human rights, A/RES/217(III) (December 10, 1948), http://www.ohchr.org/Documents/Publications/Compilation1.1en.pdf

United Nations General Assembly, World programme of action concerning disabled persons, A/RES/37/52 (December 3, 1982), https://www.un.org/development/desa/disabilities /resources/world-programme-of-action-concerning-disabled-persons.html

United Nations General Assembly, Convention on the rights of the child, A/RES/44/25 (November 20, 1989), http://www.ohchr.org/en/professionalinterest/pages/crc.aspx

United Nations General Assembly, Standard rules on the equalization of opportunities for persons with disabilities, A/RES/48/96, Annex (December 20, 1993), http://www.un.org/esa /socdev/enable/dissre00.htm

United Nations General Assembly, Convention on the rights of persons with disabilities, A/RES/61/106, Annex I, (December 13, 2006), https://www.un.org/development/desa /disabilities/resources/general-assembly/convention-on-the-rights-of-persons-withdisabilities-ares61106.html

U.S. Department of Education. (n.d.). Building the legacy: IDEA 2004 [Web page]. https://sites.ed.gov/idea/building-the-legacy-idea-2004/

"What are conflict diamonds?" (2016). Kimberley Process. http://www.kimberleyprocess.com/en/faq

World Bank. (2009). Government expenditure on education, total (\% of GDP): Botswana, Retrieved December 2020 from https://data.worldbank.org/indicator/SE.XPD.TOTL.GD.ZS

?locations $=\mathrm{BW}$

World Health Organization. (n.d.). Disability and health. Retrieved December 2020 from http://www.who.int/mediacentre/factsheets/fs352/en/

\section{Authors' Note}

This article is based on sections of the first author's PhD dissertation (Mrstik, S. M. [2017]. An examination of inclusive practices for junior secondary students with learning disabilities in Gaborone, Botswana. University of Central Florida).

Correspondence concerning this article should be addressed to Samantha Mrstik, Georgia Gwinnett College, 1000 University Center Ln., Lawrenceville, GA, 30043, U.S.A. Email: smrstik@ggc.edu 